\title{
PERDEBATAN DEFINISI DAN KRITERIA POSISI DOMINAN DALAM PERSPEKTIF REGULASI DAN EKONOMI
}

\section{Afif Hasbullah}

Fakultas Hukum Universitas Islam Darul Ulum Lamongan, Indonesia

Email: afif@unisda.ac.id

\begin{abstract}
Abstrak
Perdebatan terkait konsep posisi dominan dan implementasi penafsiran ekonomi dalam kasus persaingan usaha seringkali menjadi perhatian stakeholder persaingan usaha di dunia internasional. Di sisi lain, perdebatan menjadi makin menarik jika disandingkan dengan acuan konsep posisi dominan dalam ranah regulasi relatif tetap. Penelitian ini membahas perdebatan dan kontroversi terkait definisi posisi dominan yang tertuang dalam rumusan hukum persaingan usaha di beberapa negara. Penelitian ini bertujuan untuk mendiskripsikan pendapat dan perdebatan terkait dengan definisi dan kriteria dari posisi dominan dalam perspektif regulasi yang berlaku di Indonesia serta perspektif ekonomi yang berkembang di berbagai negara. Penelitian ini merupakan penelitian yuridis normatif dengan menggunakan pendekatan konseptual (conceptual approach), perundang-undangan (statue approach) dan perbandingan (comparative approach). Penelitian menyimpulkan bahwa Perdebatan mengenai konsep posisi dominan masih akan terus berkembang, sebagaimana perkembangan konsep ilmu ekonomi dan hukum yang melandasinya. Perbedaan substansial dalam definisi posisi dominan terdapat antara Uni Eropa dengan Amerika Serikat. Assessment posisi dominan dalam era ekonomi digital serta data driven market dan bigdata masih menjadi tantangan yang substansial ke depan.
\end{abstract}

Kata Kunci: persaingan usaha; posisi dominan; penyalahgunaan posisi dominan

\section{Abstract}

Debates related to the concept of dominant position and the implementation of economic interpretation in the case of business competition often become the attention of stakeholders in international business competition. On the other hand, the debate becomes even more interesting if it is juxtaposed with the reference to the concept of a dominant position in the realm of relatively fixed regulation. This study discusses the debates and controversies related to the definition of dominant position contained in the formulation of business competition law in several countries. This study aims to describe the opinions and debates related to the definition and criteria of the dominant position in the perspective of regulations that apply in Indonesia and the perspective of the developing economy in various countries. This research is a normative juridical research using a conceptual approach, statue approach and comparison approach. The research concludes that the debate on the concept of dominant position will continue to develop, as will the

$\begin{array}{ll}\text { How to cite: } & \text { Hasbullah, M. A. (2021) Perdebatan Definisi dan Kriteria Posisi Dominan dalam Perspektif Regulasi } \\ & \text { dan Ekonomi. Syntax Literate: Jurnal Ilmiah Indonesia, 6(1). } \\ \text { E-ISSN: } & \text { 2548-1398 } \\ \text { Published by: } & \text { Ridwan Institute }\end{array}$


development of the concepts of economics and the law that underlie it. Substantial differences in the definition of dominant position exist between the European Union and the United States. Assessment of the dominant position in the digital economy era as well as data driven markets and big data will still be a substantial challenge going forward.

Keywords: competition; dominant position; abuse of dominant position

Received: 2021-10-20; Accepted: 2021-11-05; Published: 2021-11-18

\section{Pendahuluan}

Terdapat tiga hal pokok yang menjadi substansi Undang-Undang Nomor 5 Tahun 1999 tentang Larangan Praktik Monopoli dan Persaingan Usaha Tidak Sehat (selanjutnya disebut UU Nomor 5 Tahun 1999), yakni: perjanjian yang dilarang, kegiatan yang dilarang, dan penyalahgunaan posisi dominan. Pada dasarnya, hak setiap pelaku usaha untuk menjadi besar. Dari pelaku usaha level kecil meningkat menjadi level menengah, dan dari level menengah menjadi pelaku usaha besar.

Monopoli tidak dilarang, yang dilarang adalah praktik monopoli. Demikian juga menjadi dominan tidak dilarang, yang dilarang adalah penyalahgunaan posisi dominan. UU Nomor 5 Tahun 1999 lebih menekankan kepada larangan terhadap pelaku usaha untuk berpraktik monopoli dan persaingan usaha tidak sehat. Apabila pelaku usaha menjadi monopolis dan mempunyai posisi dominan, namun dilakukan dengan cara-cara yang tidak melanggar UU 5 Tahun 1999 maupun peraturan lainnya, maka pelaku usaha tersebut tentu tidak melanggar UU 5 Tahun 1999.

Pada hakekatnya, UU Nomor 5 Tahun 1999 sangat mendorong setiap pelaku usaha untuk mempunyai daya saing. Karena dengan daya saing, akan muncul inovasi dalam rangka menghasilkan barang dan/atau jasa yang berkualitas dan kompetitif. Apabila pelaku usaha makin inovatif, berkualitas dan kompetitif, kemungkinan besar akan menjadi unggul di pasar (market leader) sehingga akan mencapai posisi dominan.

Sedangkan penyalahgunaan posisi dominan muncul ketika pelaku usaha memiliki kekuatan secara ekonomi yang memungkinkan ia untuk beroperasi di pasar tanpa terpengaruh oleh persaingan dan kemudian melakukan tindakan yang dapat mengurangi persaingan (Hasbullah, 2020). Pasal 25-28 UU Nomor 5 Tahun 1999 telah mengatur larangan penyalahgunaan posisi dominan, termasuk di dalamnya adalah terkait larangan kepemilikan saham di sektor usaha yang sama, larangan seseorang rangkap jabatan di dua atau lebih perusahaan sejenis atau yang memiliki usaha yang terkait, serta larangan penggabungan, peleburan dan pengambilalihan perusahaan yang dapat mengakibatkan terjadinya praktek monopoli dan persaingan usaha tidak sehat.

Penegakan hukum persaingan di Indonesia telah berjalan selama 21 tahun. Hal ini dihitung sejak berlakunya Undang-Undang Nomor 5 Tahun 1999 pada tanggal 5 Maret 2000. Selama kurun waktu 21 tahun, KPPU telah beberapa kali memeriksa perkara dengan tuduhan pelanggaran pasal penyalahgunaan posisi dominan, diantaranya: Perkara 05/KPPU-L/2002 mengenai Dugaan Pelanggaran terhadap Undang- undang 
Nomor 5 Tahun 1999 yang berkaitan dengan bidang perfilman dan perbioskopan; Perkara 01/KPPU-L/2003 mengenai Dugaan Pelanggaran terhadap Undang-undang Nomor 5 Tahun 1999 dalam penjualan tiket penerbangan domestik; Perkara 04/KPPUI/2003 mengenai Dugaan Pelanggaran terhadap Undang-undang Nomor 5 Tahun 1999 yang berkaitan dengan Jasa Terminal Pelayanan Bongkar Muat Petikemas ; Perkara 07/KPPU-L/2007 mengenai Dugaan pelanggaran UU No. 5 Tahun 1999 yang secara bersama-sama dilakukan oleh Kelompok Usaha Temasek dan dugaan pelanggaran UU No. 5 Tahun 1999 yang dilakukan oleh PT Telekomunikasi Seluler; Perkara 09/KPPUL/2009 mengenai Dugaan Praktek Monopoli dan/atau Persaingan Usaha Tidak Sehat Atas Akuisisi PT. Alfa Retailindo oleh PT. Carrefour Indonesia; Perkara 17/KPPUL/2010 mengenai Dugaan Pelanggaran Pasal 5, Pasal 11, Pasal 16, Pasal 25 ayat (1) huruf a Undang-Undang Nomor 5 Tahun 1999 yang dilakukan oleh Kelompok Usaha Pfizer dan PT Dexa Medica dalam Industri Farmasi Kelas Terapi Calcium Antagonis Plain dengan zat aktif Amlodipine; dan Perkara 14/KPPU-L/2015 (Perkom Nomor 01 Tahun 2010) tentang Dugaan Pelanggaran Pasal 19 huruf (a) dan (b) dan Pasal 25 ayat 1 huruf (a) dan (c) Undang-Undang Nomor 5 Tahun 1999 yang dilakukan oleh PT Forisa Nusapersada dalam Produk Minuman Olahan Serbuk Berperisa Buah yang Mengandung Susu dalam Kemasan Sachet.

Dinamika dan perubahan konsep serta doktrin ekonomi persaingan usaha terus berlangsung. Perubahan konsep dan doktrin tersebut tidak dapat dilepaskan dari perkembangan kegiatan ekonomi, model bisnis baru yang dapat kita saksikan bersama seperti fenomena industri 4.0, disruptive innovations serta era internet of things. Salah satu diskusi atau perdebatan yang seringkali menjadi perhatian stakeholder persaingan usaha di dunia internasional adalah terkait konsep posisi dominan dan implementasi penafsiran ekonomi dalam kasus persaingan usaha. Di sisi lain, perdebatan menjadi makin menarik jika disandingkan dengan acuan konsep posisi dominan dalam ranah regulasi relatif tetap.

Sebagai bagian dari komunitas dan stakeholder persaingan usaha internasional, kontroversi dan perdebatan tersebut juga dirasakan di Indonesia, khususnya terkait dengan perkara-perkara penyalahgunaan posisi dominan yang ditangani Komisi Pengawas Persaingan Usaha (KPPU). Penelitian ini akan membahas mengenai perdebatan dan kontroversi terkait pengertian atau definisi posisi dominan yang tertuang dalam rumusan hukum persaingan usaha di beberapa negara. Tujuan paper ini adalah untuk menyajikan berbagai pendapat dan perdebatan terkait dengan definisi dan kriteria dari posisi dominan dalam perspektif regulasi yang berlaku di Indonesia serta perspektif ekonomi.

\section{Metode Penelitian}

Penelitian ini merupakan penelitian yuridis normatif dengan menggunakan pendekatan konseptual (conceptual approach), perundang-undangan (statue approach) dan perbandingan (comparative approach). Bahan hukum yang digunakan terdiri dari bahan hukum primer dan bahan hukum sekunder. Bahan hukum primer terdiri dari 
peraturan perundang-undangan, yakni UU Nomor 5 Tahun 1999. Bahan hukum sekunder meliputi buku teks, kamus, jurnal dan putusan pengadilan.

\section{Hasil dan Pembahasan}

\section{A. Definisi Posisi Dominan dan Perdebatannya}

Sebagai definisi konseptual yang seringkali menjadi dasar dari penegakan hukum persaingan usaha, tentunya tidak terlepas dari berbagai kritikan, bahkan dari kalangan sesama otoritas persaingan. Definisi posisi dominan oleh European Court of Justice dapat dijadikan contoh sebagai berikut: "The dominant position referred to in this Article relates to a position of economic strength enjoyed by undertaking which enables it to prevent effective competition being maintained on the relevant market by giving it the power to behave to and appreciable extent independently of its competitors, customers and ultimately of its consumers."

Definisi posisi dominan tersebut digunakan oleh Majelis Hakim ECJ terkait kasus United Brands (1976) dan selanjutnya pada kasus Hoffman LaRoche (1978). Definisi tersebut menjadi semacam yurisprudensi dan referensi bagi kasus kasus posisi dominan selanjutnya di wilayah jurisdiksi Uni Eropa dan oleh masing masing negara anggota Uni Eropa.

Sementara, untuk contoh di negara Asia, Jepang menggunakan istilah private monopolization dengan definisi "such business activities, by which any entrepreneur, individually or by combination or conspiracy with other entrepreneurs, or in any other manner, excludes or controls the business activities of other entrepreneurs, thereby causing, contrary to the public interest, a substantial restraint of competition in any particular field of trade."

Sedangkan Korea Selatan menggunakan istilah market dominant business dengan definisi "companies with market dominance that can determine, maintain or change prices, quantity or quality of commodities or services or other terms and conditions of business as a supplier or customer in a particular business area individually or jointly with other enterprisers."

Definisi posisi dominan dalam UU Nomor 5 Tahun 1999 dapat ditemukan dalam dua pasal, yaitu pasal 1 ayat 4 dengan definisi sebagai berikut:

"Posisi dominan adalah keadaan dimana pelaku usaha tidak mempunyai pesaing yang berarti di pasar bersangkutan dalam kaitan dengan pangsa pasar yang dikuasai, atau pelaku usaha mempunyai posisi tertinggi di antara pesaingnya di pasar bersangkutan dalam kaitan dengan kemampuan keuangan, kemampuan akses pada pasokan atau penjualan, serta kemampuan untuk menyesuaikan pasokan atau permintaan barang atau jasa tertentu".

Sementara definisi yang juga terkait posisi dominan dapat dijumpai di pasal 25 ayat 2, yang merupakan bagian dari pasal 25 mengenai penyalahgunaan posisi dominan. Berikut adalah penjabaran mengenai posisi dominan dalam pasal 25 ayat (1) dan (2): 
(1) Pelaku Usaha dilarang menggunakan posisi dominan baik secara langsung maupun tidak langsung untuk: a. menetapkan syarat-syarat perdagangan dengan tujuan untuk mencegah dan atau menghalangi konsumen memperoleh barang dan atau jasa yang bersaing, baik dari segi harga maupun kualitas; b. membatasi pasar dan pengembangan teknologi; atau c. menghambat pelaku usaha lain yang berpotensi menjadi pesaing untuk memasuki pasar bersangkutan;

(2) Pelaku usaha memiliki posisi dominan sebagaimana dimaksud ayat (1) apabila: a. satu pelaku usaha atau satu kelompok pelaku usaha menguasai 50\% (lima puluh persen) atau lebih pangsa pasar satu jenis barang atau jasa tertentu; atau b. dua atau tiga pelaku usaha atau kelompok pelaku usaha menguasai 75\% (tujuh puluh lima persen) atau lebih pangsa pasar satu jenis barang atau jasa tertentu.

Sekalipun diatur dalam dua pasal yang berbeda, pengertian posisi dominan tidak saling bertentangan atau tumpang tindih. Penjabaran di pasal 25 ayat 2 lebih fokus pada kriteria pangsa pasar dengan threshold $50 \%$ dan $75 \%$. Sementara pengertian di pasal 1 ayat 4 relatif lebih luas karena juga menggunakan beberapa parameter selain pangsa pasar seperti "kemampuan keuangan", "akses pada pasokan dan atau penjualan" serta "kemampuan untuk menyesuaikan permintaan pasokan pada barang atau jasa tertentu". Penggunaan kriteria pada pasal 1 ayat 4 juga dapat diterapkan pada beberapa perilaku yang seringkali dikaitkan dengan posisi dominan lain seperti contohnya pada tying/bundling dan perjanjian eksklusif (pasal 15) dan diskriminasi serta penguasaan pasar (pasal 19) serta praktek jual rugi (pasal 20).

Amerika serikat, di satu sisi menggunakan istilah monopoly power dibanding posisi dominan. Berdasarkan Sherman Act (sect 2), monopoly power didefinisikan melalui dua pengertian yaitu kemampuan untuk menetapkan harga di atas ambang kompetitif serta mampu melakukan hal tersebut selama kurun waktu yang substansial tanpa ada gangguan atau ancaman dari new entrant atau ekspansi pesaing. Dalam konteks tersebut, pengujian market power menjadi salah satu poin penting dalam pembuktian ada atau tidaknya posisi dominan dalam penyelidikan kasus persaingan usaha di Amerika Serikat.

Mengutip dari (Foreclosure, n.d.), salah satu poin perdebatan yang mengemuka terjadi antara delegasi Amerika Serikat yang menyatakan definisi yang digunakan ECJ cenderung "unhelpful" khususnya terkait pengertian independensi. Dalam kasus yang terjadi di Amerika Serikat terkait Perusahaan Microsoft Corp, perusahaan yang bersangkutan mengajukan argumen bahwa perusahaan sekelas Microsoft pun tidak dapat bertindak sepenuhnya independen terutama terhadap selera dan preferensi konsumen. Microsoft Corp akan selalu berusaha untuk memenuhi kebutuhan dan pereferensi konsumen untuk dapat menjual produknya.

Pandangan tersebut sejalan dengan pendapat akademisi yang pada intinya menyebutkan bahwa pembuktian unsur independen sebagaimana definisi yang digunakan Hakim Uni Eropa dalam kasus Hoffman LaRoche, relatif sulit untuk dijabarkan pembuktianya, mengacu kepada pendapat (Arezanoo, 2006) sebagai 
berikut:"Because all undertakings, even near-monopolists, face a downward sloping demand curve and the pressure of competition from substitute products or services, economists claim that no firm will ever have the power to behave independently from any constraints; hence, independence is not a good proxy to infer dominance".

Terlepas dari kritikan terhadap definisi posisi dominan versi Uni Eropa tersebut, tidak otomatis menjadikan Konsep posisi dominan versi Amerika Serikat juga bebas dari kritikan. Kasus DuPont dengan Cellophane fallacies menunjukkan potensi kelemahan dari tafsir versi Amerika Serikat yang menggunakan parameter pengujian harga dan harga tingkat kompetitif tersebut. Di tahun 1956, US Supreme Court membatalkan tuduhan penyalahgunaan monopoli power oleh DuPont dengan pertimbangan pasar bersangkutan yang digunakan otoritas persiangan terlalu sempit. Dengan menggunakan metode SSNIP standar, US Supreme Court menyimpulkan bahwa pasar yang digunakan dalam kasus tersebut adalah pasar wrapping secara umum, tidak hanya yang berbasis cellophane sebagaimana digunakan dalam tuntutan otoritas persaingan. Implikasinya keputusan dari otoritas persaingan dibatalkan.

Sebagaimana yang diuraikan oleh (Bresnahan, 1989) bahwa secara konseptual, penggunakan estimasi langsung terhadap market power utamanya melalui lerner index dengan parameter Price dan Marginal Cost mengacu pada konsep Structure Conduct Performance (SCP) yang dipopulerkan oleh Bain pada era 1950an. Namun pendekatan estimasi langsung tersebut dalam perjalanannya menimbulkan kritikan oleh beberapa akademisi, yang mengajukan konsep dan metode estimasi tidak langsung terhadap parameter Price dan Marginal Cost (dalam perkembangan selanjutnya, pendekatan ini seringkali disebut New Empirical Industrial Organization atau NEIO). Beberapa dasar pertimbangan dari estimasi tidak langsung adalah bahwa accounting profit berikut data biaya dalam laporan keuangan atau laporan statistik perusahaan tidak dapat mencerminkan marginal cost sehingga tidak dapat dijadikan proxy dari market power (White, 2013). Oleh karena itu, estimasi marginal cost harus didasarkan pada estimasi biaya secara tidak langsung, diantaranya melalui comparative static baik terhadap fungsi permintaan dan fungsi biaya. Beberapa model estimasi dan pengujian market power NEIO yang banyak digunakan adalah model Panzar-Rosse dan model BresnahanLau. Aplikasi kedua model tersebut di Indonesia dapat ditelusuri dengan mengacu pada beberapa studi, antara lain (Lubis, 2012) dan juga (Syafri \& Lubis, 2008). Lebih jauh lagi kompleksitas akan meningkat apabila estimasi dilakukan terhadap produk yang terdiffrensiasi atau diffrentiated market, terkait dengan banyak nya parameter elastisitas permintaan produk yang harus dilakukan (Bresnahan, 1989).

Masih mengacu pada definisi market power pada kasus DuPont, keputusan US Supreme Court belum mempertimbangkan faktor jangka waktu terkait apakah perusahaan yang bersangkutan memiliki market power atau tidak. Mengacu pada (Schmalensee, 1985) menjelaskan bahwa perusahaan dapat saja dominan dalam 
jangka pendek dan atau jangka panjang. Dominan dalam jangka pendek apabila perusahaan memiliki share kapasitas produksi yang signifikan sehingga dapat dieksploitasi untuk short term profit. Sementara untuk dominan jangka Panjang, perusahaan tersebut harus memiliki kemampuan untuk membatasi persaingan terutama terhadap eksisting pesaing dan potensial entrant. Kemampuan tersebut bersifat posisi "long run advantages" yang dapat mencegah rival untuk mengembangkan kapasitasnya, dan potential entrant untuk invest dan masuk ke pasar. Dan dalam hal ini, size perusahaan bukan factkr yang menentukan seberapa besar "long run advantages" tersebut.

Terkait dengan durasi dari posisi dominan, (Schmalensee, 1985) menyatakan bahwa perusahaan yang memperoleh posisi dominan dalam jangka pendek biasanya melalui merger akuisisi, yang tanpa memiliki advantages terhadap pesaing eksisting, cenderung menunjukkan kinerja yang buruk dan akan kehilangan dominannya dalam waktu singkat. Dalam kondisi yang berbeda, perusahaan dengan posisi dominan dapat mempertahankan keunggulan nya apabia mereka memiliki dan memanfaatkan keunggulan yang bersifat strategis dan operasional. Dengan adanya keunggulan strategis dan operasional tersebut, perusahaan dapat mempertahankan posisi dominannya, bahkan dapat saja melakukan tindakan untuk melepas profit jangka pendek dalam rangka mempertahankan pangsa pasar nya.

\section{B. Kriteria posisi dominan}

Perdebatan juga muncul dalam penentuan posisi dominan seolah ingin menjawab pertanyaan How much is too much. Berbeda dengan definisi posisi dominan, terdapat kesamaan pandangan terkait beberapa kriteria atau parameter mengenai posisi dominan. Assesment terhadap sejauhmana pelaku usaha yang diduga memenuhi posisi dominan, menggunakan beberapa kriteria antara lain:

\section{Pangsa pasar}

Sebagai indikator pertama (setelah melewati tahapan pendefinisian pasar bersangkutan), ukuran pangsa pasar diyakini memiliki korelasi positif dengan posisi dominan. Makin tinggi market share, makin dominan perusahaan tertentu di pasar yang bersangkutan. Perdebatan terjadi pada batasan sejauhmana perusahaan dikatakan memiliki posisi dominan dengan tingkat pangsa pasar tertentu. Competition tribunal Kanada dalam contohnya menyebutkan pangsa pasar $80 \%$ dapat disebut otomatis memiliki market power, sementara pangsa pasar dibawah 50\% tidak dapat menjadi dasar bagi dugaan adanya posisi dominan.

Otoritas persaingan di Korea Selatan menggunakan indikator yang diatur dalam undang undang persaingan, dalam menentukan posisi dominan suatu perusahaan yaitu:

- Perusahaan market leader memiliki pangsa pasar 50\% atau lebih;

- Dalam pasar tertentu, tiga besar perusahan memiliki pangsa pasar gabungan sebesar $75 \%$; 
- Perusahaan dengan pangsa pasar kurang dari 10\% tidak diikutsertakan dalam assessment posisi dominan;

Dalam penerapannya, di kasus yang melibatkan perusahaan Microsoft, KFTC menyatakan bahwa perusahaan memiliki pangsa pasar $77 \%$ untuk pasar operating system PC server dan hampir $99 \%$ untuk windows operating system untuk PC biasa. Dengan indikator tersebut, Microsoft dikatakan telah memenuhi definisi market dominant company. Dalam kasus lain, perusahaan BC Card, LG Capital dan Samsung Card secara gabungan memiliki pangsa pasar 72,3\% untuk pasar cash advance services. Besaran pangsa pasar tersebut belum memenuhi kriteria market dominant company untuk tiga perusahaan terbesar (masih dibawah $75 \%$ ).

Otoritas persaingan Amerika Serikat menggunakan indikator 50\% untuk menduga bahwa perusahaan memiliki market power. Dimana pelaku usaha yang memiliki pangsa pasar dibawah 50\% dianggap tidak memiliki market power. Dalam beberapa kasus, pengadilan menyatakan perusahaan memiliki monopoly power dengan indikator market share 70-75\% untuk periode 5 tahun baru dapat dikatakan ada indikasi monopoly power. Dalam pendekatan lain, perusahaan yang memiliki pangsa pasar diatas 50\% dianggap tidak memiliki monopoly power karena tidak terbukti memiliki kemampuan untuk menentukan harga diatas kompetitif dalam jangka waktu tertentu.

Sementara otoritas persaingan EU juga menggunakan indikator pangsa pasar yang bervariasi. Dalam kasus yang melibatkan perusahaan telekomunikasi Wanadoo, didapat bukti peningkatan pangsa pasar perusahaan dari kisaran 4050\% menjadi 70-80\% dalam periode 2 tahun (selama 2000-2002). Dalam kasus lain yang melibatkan Perusahaan AztraZaneca, perusahaan tersebut dianggap memiliki posisi dominan selama lima tahun dengan pangsa pasar sekitar 80-90\% di Belgia dan sekitar 75\% di Denmark.

Beberapa kasus terkait posisi dominan yang sudah ditangani oleh KPPU (khususnya pasal 25) juga menggunakan indikator pangsa pasar sebagai kriteria posisi dominan (sebagaimana memenuhi unsur pasal 25 ayat 2). Contoh kasus tersebut antara lain adalah perkara nomor 06/KPPU-L/2004 terkait dugaan penyalahgunaan posisi dominan untuk pasar produk batu baterai. Dalam kasus tersebut majelis komisi menilai terlapor sudah memenuhi kriteria sebagai perusahaan dengan posisi dominan berdasarkan kriteria pasal 25 ayat 2 dimana pangsa pasar mencapai $88 \%$ (melebihi batasan threshold 50\% untuk satu pelaku usaha). Dalam kasus lain yang masih terkait dengan dugaan pelanggaran penyalahgunaan posisi dominan (Perkara Nomor: 14/KPPU-L/2015 terkait produk minuman olahan serbuk berperisa buah), Majelis Komisi menyatakan perusahaan terlapor, memenuhi kriteria posisi dominan berdasarkan kriteria pangsa pasar yang mengacu pada definisi posisi dominan di pasal 1 ayat 4 (pangsa pasar antara 80-84\% selama periode pelanggaran). Berbeda dengan contoh kasus batu baterai yang menggunakan kriteria pangsa pasar berdasarkan 
pasal 25 ayat 2, Majelis komisi perkara menyimpulkan bahwa perusahaan terlapor memiliki posisi dominan karena "tidak memiliki pesaing yang berarti dalam pasar bersangkutan" berdasarkan indikator penguasaan pangsa pasar sebagaimana dimaksud dalam pasal 1 ayat 4 .

\section{Entry barrier (hambatan masuk pasar)}

Entry barrier terbagi atas barrier regulasi dan barrier yang dibangun oleh incumbent (dalam bentuk skala ekonomi dan atau efek network). Hambatan regulasi pada umumnya paling banyak dijumpai dalam bentuk regulasi atau peraturan perijinan dan akses untuk masuk ke pasar. Sementara hambatan yang berupa skala ekonomi atau network effect, umumnya bersifat akumulatif jangka panjang, dimana pelaku usaha (incumbent) membutuhkan waktu dan skala investasi yang besar untuk mengembangkan kapasitas produksi dan jaringan distrbusi yang bersifat barrier bagi perusahaan lain. Makin tinggi barrier dikonotasikan dengan dampaknya yang memperkuat posisi dominan oleh incumbent, dan sebaliknya.

Penerapan analisa terkait entry barrier juga bervariasi antar otoritas karena tidak ada bentuk, kriteria atau parameter yang bersifat universal sebagaimana pangsa pasar. Otoritas pengadilan Amerika serikat dalam kasus Microsoft Corp dengan pangsa pasar mencapai 95\% menyatakan bahw walaupun pangsa pasar Microsoft mencapai 95\% (dengan istilah dominantpersistent dan increasing market share) tetap belum cukup untuk dikatakan memenuhi definisi monopoly power. Otoritas pengadilan menyatakan bahwa faktor entry barrier dalam kasus ini berupa teknologi aplikasi yang mempertimbangkan kebutuhan dan preferensi paling tidak dua pihak yaitu user konsumen dan para pembuat aplikasi. Pendekatan pasar bersangkutan yang digunakan dalam kasus ini dikenal dengan istilah two sided market atau multisided market. Suatu kondisi dimana terdapat operator (platform) yang berinteraksi dengan dua atau lebih pengguna, dimana terdapat cross network effect antar pengguna. Konsep multisided market seperti ini mengacu ke beberapa publikasi, diantaranya (Hagiu \& Wright, 2015) dan (Yang, 2018).

Penerapan analisa entry barrier di Korea Selatan menunjukkan kondisi yag serupa. Dalam kasus yag melibatkan Microsoft untuk pasar OS PC server dan OS PC, otoritas persaingan berpendapat bahwa dibutuhkan skala teknologi, SDM dan waktu serta investasi modal yang substansial sebagai yang disebut economic and technological entry barrier. Dalam kasus lain yang melibatkan perusahaan kartu kredit, regulsi yang mensyaratkan perijinan dari government agency dianggap sebagai salah satu entry barrier karena sejak 1995 tidak ada perijinan baru untuk new comers, secara tidak langsung menjadikan struktur pasar stabil bagi incumbent.

Penerapan analisa entry barrier di otoritas EU dapat dijumpai pada contoh kasus Wanadoo (perusahaan telekomunikasi-OTT). Otoritas pengadilan persaingan berpendapat bahawa penguasaan jaringan distribusi serta Kerjasama 
eksklusif dengan perusahaan perusahaan advertising dapat dianggap sebagai hambatan untuk masuk ke pasar oleh pesaing potensial. Dalam kasus lain yang melibatkan Astra Zaneca di sektor farmasi, bentuk entry barrier dijumpai dalam bentuk penguasaan HAKI (IP rights) dimana sampai patennya habis, ijin untuk masuk ke pasar produk obat tertentu membutuhkan proses dan biaya signifikan terkait ujicoba pre klinis dan klinis.

\section{Buyer power (Daya tawar Pembeli)}

Parameter buyer power terkait dengan pihak yang berlawanan dalam transaksi dengan perusahaan yang diduga memiliki posisi dominan. Sejauhmana pihak tersebut memiliki daya tawar dan kekuatan untuk melakukan negosiasi dengan perusahaan yang diduga dominan. Makin tinggi daya tawar atau kekuatan negosiasi para pembeli, makin rendah potensi dominan oleh perusahaan yang bersangkutan, dan sebaliknya. Sebagaimana entry barrier, assessment terhadap buyer power juga cenderung tidak memiliki kriteria atau indikator yang universal atau cenderung kualitatif.

Contoh penerapan assessment terhadap buyer power dapat dijumpai di Korea Selatan, dimana dalam kasus yang melibatkan perusahaan kartu kredit, salah satu jasa yang ditawarkan adalah cash advance services. Bentuk jasa tersebut dianggap sebagai alternatif dari jasa pemberian kredit yang umumnya membutuhkan prosedur formal yang panjang. Karena produk pembiayaan sulit untuk dijangkau atau dijumpai oleh konsumen, maka penawaran cash advancement oleh perusahaan kartu kredit dianggap satu satunya alternatif pembiayaan yang feasible bagi konsumen. Pengamatan otoritas persainhgan menunjukkan elastisitas permintaan yang makin kecil untuk produk tersebut. Bahkan dalam kondisi terjadi kenaikan suku bunga untuk cash advancement tersebut, permintaan terhadap produk yang bersangkutan tetap meningkat.

Contoh lain mengenai buyer power juga dapat dijumpai dalam kasus Astra Zaneca yang ditangani oleh otoritas persaingan Uni Eropa. Sebagaia bagian dari pembelaan perusahaan, adanya posisi pembeli yang bersifat monopsoni dan peraturan batasan harga menjadi faktor yang mematahkan tuduhan adanya posisi dominan oleh perusahaan yang bersangkutan. Posisi monopsoni buyer dikaitkan dengan kebijakan asuransi dan perlindungan kesehatan sosial (social coverage) dimana pihak penyelenggaran jaminan akan menjadi pihak yang melakukan negosiasi lansung dengan perusahaan farmasi berdasarkan aturan harga yang ditetapkan regulator. Pertimbangan dari otoritas persaingan EU untuk menolak arguman yang disampaikan perusahaan didasarkan pada dua kondisi yaitu demand terhadap obat cenderung inelastic dimana pasien pada umumnya tidak melakukan negosiasi langsung dan telah menjadi bagian dari sistem asuransi kesehatan. Faktor kedua adalah walau harga telah diregulasi, namun yang menentukan berapa banyak produk obat untuk dikonsumsi (dosis penggunaan) adalah tenaga medis, sehingga biaya 
pembelian obat (harga dikali volume pembelian) tidak menjadi keputusan pasien semata.

\section{Teknologi, inovasi dan efek jaringan}

Perkembangan teknologi dan innovasi umumnya mengarah kepada efisiensi dan produktifitas. Namun dalam konteks ini, inovasi dan teknologi yang berkembang diduga dapat menguatkan posisi dominan pelaku usaha tertentu sebagaimana yang terjadi dengan perusahaan-perusahaan teknologi yang harus berurusan dengan otoritas persaingan di berbagai negara (kasus yang melibatkan google, Microsoft facebook dan lain-lain). Dalam kondisi ini, kemungkinan posisi dominan yang dikaitkan dengan teknologi dan inovasi, banyak berhubungan dengan konsep data driven market dan atau penguasaan bigdata. Pendalaman mengenai posisi dominan dan bigdata ini dapat mengacu pada beberapa publikasi, antara lain MGI: (Manyika et al., 2011).

Efek jaringan dan skala ekonomi dalam penguasaan dan pengolahan bigdata dapat menjadi salah satu faktor entry barrier yang menguatkan posisi dominan perusahaan tertentu, sebagaimana pendapat beberapa studi yang dirangkum oleh (Ciuriak, 2018). Efek entry barrier juga dapat ditimbulkan oleh penguasaan HAKI (IP rights) terkait teknologi yang berpotensi meningkatkan konsentrasi pasar (Wagner, 2015).

Terdapat semacam kesamaan pandangan bahwa kriteria market share dapat menjadi indikator awal sebuah perusahaan memiliki posisi dominan, namun satu indikator tersebut saja tidak cukup. Assessment harus dilakukan dengan mempertimbangkan kriteria lain seperti yang sudah dibahas diatas. Poin perdebatan pro kontra banyak berkisar kepada sejauhmana satu kriteria bisa mempengaruhi analisa posisi dominan berbanding dengan kriteria lainnya.

Belum lagi terdapat kondisi yang menunjukan bahwa kriteria non market share lebih banyak bersifat subyektif dan kualitatif, sehingga penggunaanya dari sisi validitas masih banyak menjadi perdebatan para pihak. Sebagaimana diuraikan oleh Eberhard (2006) bahwa Komisioner EU beberapa kali menggunakan parameter sosial dan politik untuk memperkuat assessment terkait posisi dominan. Kondisi terdebut berpotensi melewati cakupan hukum persaingan usaha seperti masuk dalam wilayah perlindungan UMKM dan aspek lain. Dalam paper yang sama, Eberhard (2006) juga menyampaikan: "The Commission' $s$ flexible criteria of analysis increase the problem of legal uncertainty that undertakings face when they act on the European market. This legal uncertainty has grown with the Court of First Instance holding that the Commission must restate the actual relevant market and the conditions of competition whenever it applies Article 82 EC".

Sebagaimana disampaikan oleh Arezano (2006) bahwa penggunaan faktor di luar market share cenderung menimbulkan ketidakjelasan dalam penentuan dominan terutama terkait interaksi antar berbagai kriteria tersebut. Apakah diperlukan mekanisme pembobotan dimana kriteria market share 
memperoleh bobot yang lebih besar dibanding kriteria lain. Skenario yang mungkin terjadi dengan implementasi multiparameter terkait dugaan posisi dominan dapat mengarah ke dua bentuk kemungkinan.

Skenario pertama dimana ada perusahaan (PT. A) dengan market share secara meyakinkan diatas batas dominan (> 80\%). Terdapat kekhawatiran bahwa parameter pangsa pasar yang signifikan akan melaihrkan presumptions bahwa perusahaan tersebut harus terbukti dominan, sehingga otoritas persaingan akan mencari justifikasi tambahan melalui tiga kriteria lain (dengan argumen kualitatif dan kuantitatif). Dalam kondisi ini, pihak perusahaan dan pengacara akan berusaha (secara all out) untuk menggunakan tiga parameter lain (entry barrier, buyer power dan teknologi innovasi) untuk mematahkan dugaan awal posisi dominan berdasarkan pangsa pasar. Concern ini disampaikan oleh White (2013) yang pada intinya adalah menyampaikan bahwa penghitungan market power melalui selisih antara price dengan marginal cost cenderung beresiko dalam penafsirannya. Setiap selisih positif antara harga dengan marginal cost akan selalu dikonotasikan dengan market power. Bahkan dalam kondisi dimana perusahaan yang efisien berusaha untuk memperbesar posisi startegis nya dibanding pesaing, yang kemungkinan akan mengakibatkan deviasi harga diatas marginal cost.

Skenario kedua, dimana ada perusahaan yang penguasaan pangsa pasar nya masih di bawah threshold tertentu (contoh < 30\%) akan tetapi terdapat informasi yang menunjukkan adanya entry barrier yang signifikan, kesulitan konsumen untuk beralih ke produk lain serta terdapat skala teknologi-jaringan yang memungkinkan perusahaan tersebut untuk mengeksploitasi pasar yang bersangkutan secara unfair. Sejauhmana respon dari otoritas persaingan yang "terikat" untuk menggunakan parameter pangsa pasar sebagai indikator awal. Tentunya kembali akan terjadi adu argumentasi terkait pembuktian ketiga parameter (selain pangsa pasar) yang akan menentukan sebuah perusahaan memiliki posisi dominan atau tidak.

\section{Kesimpulan}

Perdebatan mengenai konsep posisi dominan masih akan terus berkembang, sebagaimana perkembangan konsep ilmu ekonomi dan hukum yang melandasinya. Perbedaan substansial dalam definisi posisi dominan terdapat antara Uni Eropa dengan Amerika Serikat. Namun demikian, tafsir dan metodologi dalam penentuan posisi dominan yang terjadi antar otoritas persaingan relatif homogen terutama mengenai krieria yang digunakan. Masih terdapat ruang dimana perdebatan konsep dan metodologi terutama terkait interaksi antar kriteria yang diperlukan untuk menentukan seberapa besar peluang perusahaan untuk memenuhi kriteria posisi dominan. Lebih jauh lagi, assessment posisi dominan dalam era ekonomi digital serta data driven market dan bigdata juga akan menjadi tantangan yang substansial ke depan. 


\section{BIBLIOGRAFI}

Bresnahan, Timothy F. (1989). Empirical studies of industries with market power. Handbook of Industrial Organization, 2, 1011-1057. Google Scholar

Ciuriak, Dan. (2018). The economics of data: implications for the data-driven economy. Google Scholar

Foreclosure, Predatory. (n.d.). Evidentiary Issues in Proving Dominance. Google Scholar

Hagiu, Andrei, \& Wright, Julian. (2015). Multi-sided platforms. International Journal of Industrial Organization, 43, 162-174. Google Scholar

Hasbullah, M. Afif. (2020). Penegakan Hukum Persaingan Usaha Dalam Sektor Ekonomi Digital. Jurnal Ilmiah MEA (Manajemen, Ekonomi, \& Akuntansi), 4(1), 582-597. Google Scholar

Lubis, Andi Fahmi. (2012). Market Power Perbankan Indonesia. Buletin Ekonomi Moneter Dan Perbankan, 14(3), 235-255. Google Scholar

Manyika, James, Chui, M., Brown, B., Bughin, J., Dobbs, R., Roxburgh, C., \& Byers, A. H. (2011). Big data: the next frontier for innovation, competition, and productivity. McKinsey Global Institute, McKinsey \& Company. Insights \& Publications. http://www. mckinsey. com/Insights/MGI/Research ... Google Scholar

Schmalensee, Richard. (1985). Standards for dominant firm conduct: what can economics contribute? Google Scholar

Syafri, Yan, \& Lubis, Andi Fahmi. (2008). Estimasi Tingkat Persaingan Dalam Industri Perbankan Indonesia: Pendekatan Panzar-Rosse Model. Jurnal Kebijakan Ekonomi, 4(1), 1-16. Google Scholar

Wagner, Stefan. (2015). Are 'Patent Thickets' Smothering Innovation? Yale Insights, 22. Google Scholar

Yang, Sung Yoon. (2018). Rethinking modes of market definition for multi-sided platforms. International Journal of Trade, Economics and Finance, 9(4), 164-169. Google Scholar

Copyright holder:

M. Afif Hasbullah (2021)

First publication right:

Syntax Literate: Jurnal Ilmiah Indonesia

This article is licensed under:

Syntax Literate, Vol. 6, Spesial Issue No. 1, November 2021 